DOI: 10.1515/ausp-2015-0037

\title{
The Pilgrimage as Inner and Outer Journey in Paulo Coelho's The Pilgrimage
}

\author{
Vilma-Irén MIHÁLY \\ Sapientia Hungarian University of Transylvania (Miercurea Ciuc, Romania) \\ Department of Humanities \\ vilma_gote@yahoo.com
}

\begin{abstract}
The present paper aims at analyzing the significance and occurrence of pilgrimages as inner and outer journeys, focusing on their form(s) and role(s) in today's postmodern society. The introductory part presents the phenomenon from a theoretical point of view, that is taking into consideration its possible definitions (e.g. as a religious phenomenon in pre-Christian and Christian cultures from the Middle Ages to the present; and pilgrimages in literature). The core of the paper then discusses Paulo Coelho's novel entitled The Pilgrimage. A Contemporary Quest for Ancient Wisdom, which, though extremely popular, has not yet undergone any significant literary analysis. We shall examine the protagonist's spiritual journey from the perspective of the postmodern human condition. The questions that the paper tries to answer also refer to the relationship between the novel and different religions such as Christianity and New Age, respectively neo-pagan movements that are the product and proof of postmodern pluralism at the same time.
\end{abstract}

Keywords: pilgrimage, inner and outer journey, the postmodern condition

Pilgrimages have been present in mankind's history from ancient times up to our days. Usually they are a special type of journey undertaken for a religious motive with pilgrims seeking a certain place which has been sanctified being connected to the Divine or a Saint (Encyclopædia Britannica). By going on the journey pilgrims hope to become part of something bigger than them, and to be able to communicate with higher spiritual spheres. Although pilgrimages can be found in and are practiced by all world religions, they cannot be reduced to religious journeys only. In the past the search for miracles of divine origin might have been the driving force for pilgrims, yet today it has become much more important to find oneself, one's own path in life, so that parallel to the outer physical journey there is an inner journey towards the soul: "A pilgrimage entails a journey from one place to another, from one aspect of one's life to another. As a result of this movement, many people experience pilgrimage as a transformation” (Gesler 1996, 95-105). 
The academic study of pilgrimage has received attention from many fields such as cultural anthropology, archaeology, art, history, geography, the sociology of religion and/or theology. Thus, pilgrimage is a field of cross- and interdisciplinary interest and focus, and each academic discipline brings unique questions and answers on the topic.

In cultural anthropology, for example, the Turners (2011) interpret the experience of pilgrimage through the concepts of liminality and communitas. Liminality is a term borrowed from Arnold van Gennep" expressing "in-betweenness" within a rite of passage as an individual moves from one social state to the other. Such passage rites usually consist of three stages: first, the individual has to separate from a previous group, then he/she enters the "in-between" or liminal phase, where many things change or get distorted and finally, his/ her reintegration into the community takes place entering a new social state. Liminality is characteristic of the second stage/phase where the rules of normality do not apply, because it is a place between the worlds (Ross 2011, 5-26).

Communitas, on the other hand, names the experience of belonging to the group of those who have undergone such a rite of passage together and as a consequence now feel united. Communitas functions as a pattern of sociality, a mode of experiencing unity with others beyond the rite of passage. Yet, the model of sociality it offers differs from the usual rules of society in the sense that commonplace distinctions do not work here, therefore people can see each other as equal. Thus, the organization of society depends on the structure/antistructure cultural dynamic: The individual takes part in the rite of passage, experiences communitas/antistructure returning to the structure of everyday society as a new person (Ross 2011, 5-26).

Liminality and communitas can very well be observed in the context of indigenous passage rites in Africa, India or Japan, where the Turners conducted their fieldwork. In modern Western society it is pilgrimages that provide a liminal experience for the pilgrim, and this way Christianity itself could develop its particular mode of liminality through its own pilgrimages (Ross 2011, 6). However, there is a slight difference between indigenous passage rites and their liminal experience, since in today's postindustrial Western society these are rare and diminished, the phenomenon has become secularized (Ross 2011, 5-26). Thus, it would be perhaps more accurate to describe today's pilgrimages which are voluntary acts as both liminal and liminoid experiences. Although pilgrimages are part of a religious ritual, individuals can decide for themselves

1 In his famous work, The Rites of Passage (1960), van Gennep states that the population of society is divided into several groups. As individuals find some groups more important than others, they might decide to change groups, leave one to enter the other within a rite of passage. The liminal stage is the second one, in-between states and conditions and is also called transition phase (van Gennep 1960). 
whether they want to participate in the event or not, they break with society and become actors in a different play for a while (liminoid experience).

Following the Turners' line of thought one can distinguish four types of pilgrimages, the first two of which occur in all the historical religions, with numbers three and four being specific of Christianity (cf. Turner and Turner 2011, 26-33):

1. Prototypical pilgrimages were established by the founder of a historical religion or his first disciples; these are documented and are supported by some strong evidence provided by an authority. Examples of such pilgrim sites are Jerusalem and Rome for Christianity, Mecca for Islam, and Mount Kailas for Hinduism, or Kandy for Buddhism.

2. Archaic pilgrimages bear evident traces of syncretism with older religious beliefs and symbols, for example, Glastonbury in England with its Celtic pagan roots, or Chalma in Mexico with Aztec remnants.

3. Medieval pilgrimages are perhaps the most popular ones nowadays, also best known through the literary works of the Christian world. They have their origin in the European Middle Ages and are influenced by the philosophical and theological trends of that period. Notable examples are Canterbury in England, Chartres in France, Assissi in Italy, or Compostela in Spain.

4. The modern, that is postmedieval pilgrimages, which appeared in the $19^{\text {th }}$ and $20^{\text {th }}$ centuries, begin with a vision and are kept alive by the belief that a miracle is sure to happen. Their tone is devotional and characterized by the personal piety of the believers. Although the adherents consider mass technology and science as a challenge to Christian world view, they make use of it as a source of aid. The best examples are the Marian pilgrimages.

As a universal phenomenon, pilgrimages have also long been an area of literary interest. Quest literature abounds with stories of pilgrimages - understood in its widest sense, from fairy tales to classics like Homer's Iliad and Odyssey, Eschenbach's Parsifal, Chaucer's The Canterbury Tales, Boccaccio's The Decameron, Cervantes's Don Quixote, Bunyan's The Pilgrim's Progress to modern fantasy literature and contemporary fiction, as, for example, Paulo Coelho's The Pilgrimage to be discussed here. In most of the cases the main characters undertake physical journeys that are metaphors for an inner journey of self-discovery and understanding.

Coelho's novel under discussion was first published in 1987 in Portuguese with the title $O$ diário de um Mago, that is A Diary of a Mage, and it became one of the author's bestsellers being translated into no less than 38 languages. The novel with autobiographical traces - Coelho wrote it after having completed the El Camino himself - got the English title The Pilgrimage. A Contemporary Quest for Ancient Wisdom, describing the initiation journey of the protagonist. 
The novel begins in medias res with the main character, the thirty-eight year old Paulo being about to receive full initiation from his Master into an ancient and mysterious religious order called RAM. Having survived many trials Paulo feels he has learnt his lessons, therefore, he buries his old sword, which stands for the knowledge gained until that point. He is confident that he is going to be awarded a new sword, the symbol of his success and of the promise that he can remain on the path of Tradition. However, when he reaches out for the new sword, his Master steps onto his hands and says that he has failed to learn the last lesson. He has become too proud of his knowledge, in fact he should have refused the sword, and then it could have been his, and he were a Magus now. Yet, because of his avidity, he has to start the journey, the quest for the sword all over again, this time taking the path of the simple folk. Seven months pass before Paulo eventually decides to follow his inner voice and begins the journey suggested to him.

The pilgrimage his Master wants him to undertake lasts seven hundred kilometers setting out from Saint-Jean-Pied-de-Port in France to Santiago in Spain. This route has been followed by pilgrims from ancient times up to now and is known as El Camino [The Way/Road]. At the end of his journey Paulo will have to arrive in the town of Compostela/Santiago where there is the tomb of San Tiago/Saint James, an evangelist, who spread Christ's teachings after the crucifixion.

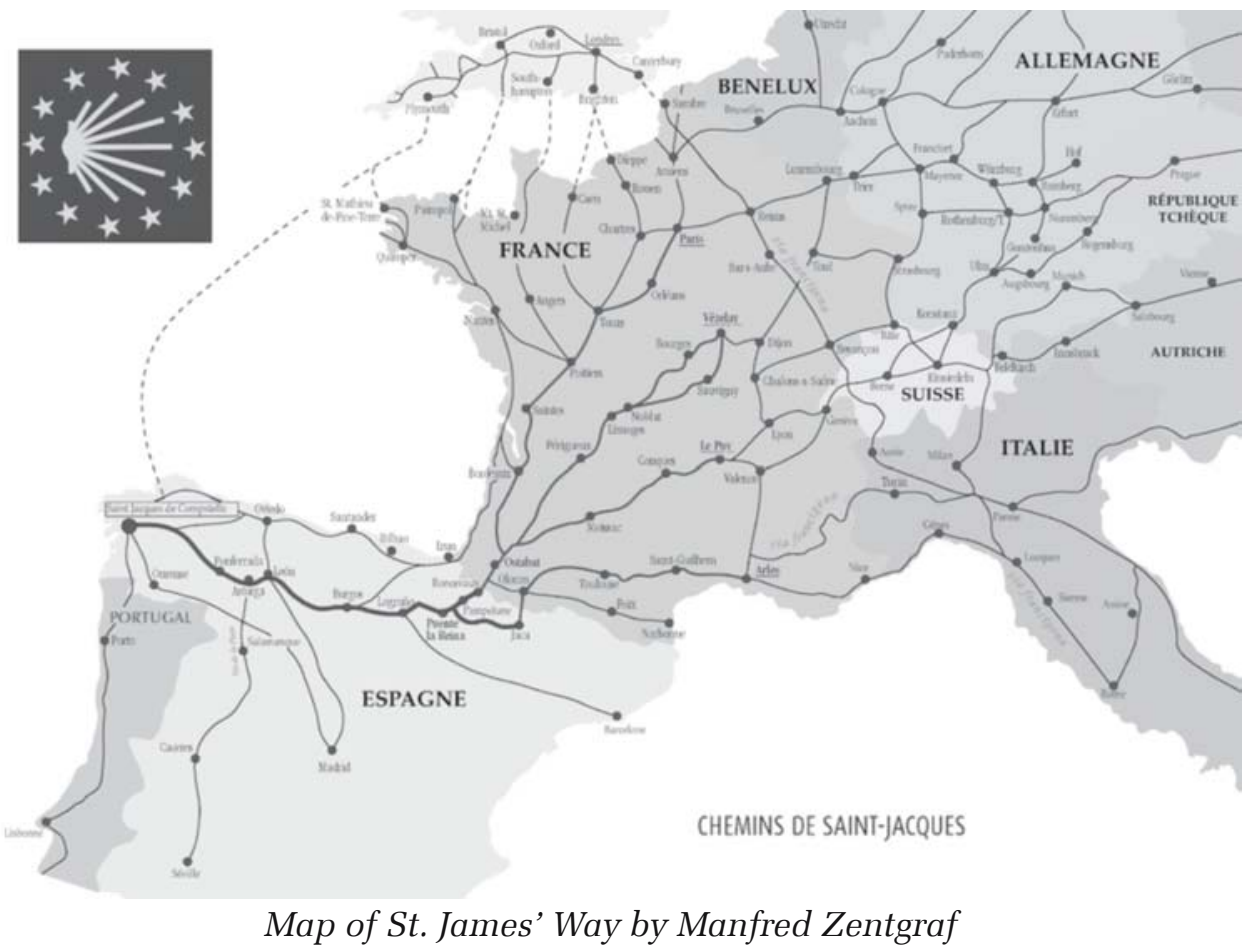

Map of St. James’ Way by Manfred Zentgraf 
Throughout his journey Paulo is being helped by Petrus, who has already achieved the title of Master and who now shall guide others in the same quest. Both Paulo and Petrus are members of RAM, a kind of Catholic sect for the study of symbols of the Opus Dei. The name of the order stands for Regnus Agnus Mundi, Rigour, Adoration and Mercy (Coelho 2004, 2). During the journey, Petrus teaches Paulo eleven RAM exercises meant to make his search for the sword easier. Among the exercises there are methods of relaxation, meditation, of calling upon a divine messenger for help, of facing death, of finding the right solution to a problem, and of developing universal love for the whole world and all human beings. The order of the exercises is not arbitrary either, Petrus teaches them in a certain sequence as they progress on the way to Santiago: the Seed Exercise - experiencing rebirth, the Speed Exercise - paying attention to the road, the Cruelty Exercise - revealing the connection between physical and spiritual pain, the Messenger Ritual - establishing communication with a divine messenger, the Arousal of Intuition (the Water Exercise) - awakening and manifesting intuition, the Blue Sphere Exercise - experiencing universal love, the Buried Alive Exercise - cause and effect, experiencing the Absolute, the RAM Breathing Exercise - experiencing harmony with the world, the Shadows Exercise - helps to find the correct solution, the Listening Exercise - learning how to distinguish among different voices and choose the right one, the Dance Exercise - dancing as a process of communication with the Infinite Intelligence (Coelho 2004). Petrus's teachings culminate when he talks about the three forms of love: eros as intimate love, philia as friendship and affection, and agape, brotherly love, the love of God for mankind and of mankind for God.

During his quest/pilgrimage Paulo meets Mme Lourdes, Father Jordi, Alfonso, Andrew and a lamb, who all help him and offer assistance. Yet, there are characters like Legion, a gypsy, and some little boys, who try to hinder him so that he cannot reach his goal. The figure of Astrain fulfills a double function, sometimes he is helpful, at other times his advice turns out to be bad. Nevertheless, all the places and people Paulo encounters during his journey strengthen him, he will become better and better in choosing/filtering the advice and information he needs in order to find his sword. It is not only the objective to reach that is important, but also the path itself and all the encountered details. He must endure physical hardship, besides walking the seven hundred kilometers, he has to climb a fiftyfoot waterfall, fight with a demonic black dog and raise a wooden cross that has fallen. Thus, Paulo's journey is a mental, physical and spiritual one, at the end of which, having understood that the extraordinary can be found in the simple way of life of common people, he succeeds, and at last his Master hands him the sword. He constantly has had to search within himself for the truth behind the sword he so desperately wanted to receive. Parallel to the outer journey, there was an inner quest, one of discovery, finding one's own path. The secret of his 
sword is his only, he wrote it down and placed it under a stone, but the rain must have destroyed it. Knowledge goes beyond palpability, though, and things happen orchestrated by some higher truth, for "people always arrive at the right moment at the place where someone awaits them" (Coelho 2004, 265).

Mysticism is one of the major themes in the novel that together with the various metaphors and symbols, the poetic language and the message contribute to the popularity of the book. In the novel we have some of the mystic rituals explained, and with a couple of exceptions we are dealing with exercises that according to the author do really work and can be practiced by the readers themselves. Thus, the novel becomes a spiritual guidebook. As such, it can be regarded as the messenger of a certain type of what we could call postmodern spiritual narrative. Since the postmodern is distrustful of meta-narratives, there is a plurality of small narratives that compete with each other (cf. Lyotard 1984). We can read Coelho's Pilgrimage as such a small narrative, especially if we take into consideration the relationship between postmodernism and the pagan meta-culture.

Meta-culture represents the deepest cultural layer possible and consists of a set of beliefs and symbols that originate in archaic times and that have been renewed several times throughout history (cf. Tiryakian 1996). Although it usually goes unnoticed, meta-culture functions as the operational system of civilization. There are three major meta-cultures, namely the Christian, the Gnostic and the Pagan. Out of the three, postmodern philosophy conspires with the Pagan metaculture which manifests in form of different religious groups such as the New Age movement, neo-pagan ${ }^{2}$ or ethno-pagan communities. One of the main ideas behind these new religious movements is pluralism concerning religious belief and worldview in general, also true of the postmodern condition, where we lack a certainty of ideas, and are left with better or worse interpretations only (cf. Lyotard 1984). In the following we shall briefly discuss some of the main characteristics of the new religious movements, as the novel presented also makes use of them. Each of these new religious movements is trying to give some sort of explanation to the phenomena around us, a genuine interpretation of the world and of the aim of one's personal life. There may be differences between these new religious groups, yet the similarities between them are far more striking, e.g. they all involve the process of re-mythologizing and are characterized by an environment-conscious thinking and way of life (cf. Kis-Halas 2005). In many aspects neo-pagan movements resemble the belief system of the New Age (cf.

2 Neopaganism, in opposition to historical Pagans of ancient cultures, is an umbrella term covering a whole range of syncretic this-worldly anti-authoritarian nature-oriented modern urban protest religions, originating from European Mysticism as well as $18^{\text {th }}$ and $19^{\text {th }}$ centuries' Romanticism and reconstituted from ancient classical cults, Pre-Christian religions and non-European tribal beliefs. They are generally polytheistic or conditionally monotheistic, privileging the experience of personal ritual over belief, with some relevant common characteristics, such as re-mythologizing, ecologism, recognition of the female principle (Hubbes and Bakó 2011, 129). 
Szilágyi and Szilárdi 2007). Yet, whereas New Age rarely mentions God, because the Almighty is thought of as impersonal, cosmic energy, neo-pagans believe in concrete deities fulfilling certain functions. Regarding revelation New Age adherents believe in teachings coming from supernatural beings (angels, ghosts) or chosen persons. Neo-pagan groups do not know the idea of revelation. To them mystic knowledge stems from their ancestors and personal experience gained during the rituals. Liberation is a central theme within New Age teachings; the primary goal of the followers is to achieve perfection at the end of one's life path and to become united with God, the cosmic energy. On this way one can make use of various techniques from transcendental meditation to positive thinking and Yoga. Again, this kind of perception is foreign to neo-pagan groups. The emphasis lies much more on the intensity of life, on experiencing the here and now as much as possible. The here and now perspective is also true of the mode these neo-pagan movements see history. The focus is once more on the present, while New Age people are waiting for a new era and a messiah. As far as holidays and celebrations are concerned, New Age adherents do not really hold any. There are meetings and various ceremonies, but the institution of priesthood is unknown to them, they have teachers, gurus and masters. Neo-pagan celebrations follow a certain tradition and are connected to the cycles of nature. They pay particular attention to rituals regarding birth, marriage or death. While the New Age promotes individual practice, in neo-pagan movements initiates conduct the ceremonies in closed convents with priests as leaders. Although the New Age refers to some religious traditions such as Buddhism, Christianity or Gnosticism, it borrows only a couple of elements from these and uses them in a specific way. Neo-pagan groups reach back to various archaic traditions, since their aim is to reconstruct these religious systems. Thus, we can conclude that while New Age and neo-pagan movements share a lot of similarities, they are two different phenomena both responding to the broken character of the postmodern era. New Age combines philosophies from the East with spirituality, esoteric teachings, psychology, quantum physics or biology and is more individual than neo-pagan movements that adhere to archaic traditions, have deep national roots and their adherents often undergo specific initiations (cf. Szilágyi and Szilárdi 2007).

Many of the above mentioned features of both neo-pagan movements and New Age can be found as major themes in Coelho's present novel. Therefore, on the one hand, the novel is to be read as a product of postmodern pluralism of religious, literary and philosophical trends. On the other hand, the use of a wide range of religious and mythical symbols and topics expresses precisely the same pluralism itself. As a result, the novel can best be characterized by syncretism in its use of different religious and philosophical beliefs and symbols. The pilgrimage itself as we have seen is part of the Christian tradition, according to the Turners' classification it belongs to the category of medieval pilgrimages. However, the 
exercises described, the rituals presented reveal a tradition that most probably precedes Christianity and has archaic roots. According to the novel, Paulo is a member of the order of RAM, which is somehow related to Catholicism, yet the exercises he does are unknown to the majority of the everyday practitioners. There is an exclusivity surrounding RAM and the initiation journey, which bring Paulo's experience close to the ones described in neo-pagan movements. However, in many instances his path takes individual turns, he has a Master and the rituals he performs combine Buddhist meditation techniques with different esoteric practices, e.g. the seed exercise, where Paulo has to kneel down, sit on his knees, bend forward so that his head touches his knees. Then he stretches his arms behind himself, getting into a position resembling that of the fetus. He relaxes by breathing calmly and deeply. The picture arising within him is that of a seed, which will slowly start to grow. Parallel to the growth of the seed, Paulo stretches as if he wanted to reach the sun, until he became huge. This is an exercise meant to offer its practitioner the experience of rebirth, an idea which is accepted by New Age, but not by neo-pagan groups.

Thus we may conclude that the narrative abounds in elements taken from New Age and/or neo-pagan movements, which all emphasize that the novel itself is a product of the Pagan meta-culture combined with postmodern life philosophy. The protagonist's experience belongs to the liminal phase within the rite of passage, manifested in form of a pilgrimage. Yet, as a postmodern phenomenon involving a voluntary act it becomes a liminoid experience at the same time. The Prologue and the Epilogue of the novel clearly mark the beginning and the end of Paulo's inner and outer journey. The whole El Camino is an "in-between" phase for the protagonist, followed by his reintegration into society as a newborn person, having learnt that in order to succeed in finding his own path not only knowledge was needed but also humility towards the simple folk, towards life itself.

\section{Works cited}

Encyclopædia Britannica. Encyclopædia Britannica Online http://www. britannica.com/EBchecked/topic/460445/pilgrimage (22 Apr. 2015)

Coelho, Paulo. 2004. The Pilgrimage. A Contemporary Quest for Ancient Wisdom. Trans. by Alan R. Clarke. New York: HarperCollins.

van Gennep, Arnold. 1960. The Rites of Passage. Trans. by Monika B. Vizedom and Gabrielle L. Caffee. London: Routledge and Kegan.

Gesler, W. M. 1996. Lourdes: Healing in a Place of Pilgrimage. Health and Place vol. 2 no. 2.: 95-105.

Hubbes, László-Attila and Bakó, Rozália-Klára. 2011. Religious Minorities’ Web Rhetoric: Romanian and Hungarian Ethno-Pagan Organizations. Journal for the 
Study of Religions and Ideologies, vol. 10, no. 30 (Winter): 127-158. http://jsri.ro/ojs/index.php/jsri/article/viewFile/550/516 (22. Apr. 2015)

Kis-Halas, Judit. 2005. Újboszorkány kultuszok a 20. században. A wiccától a cyberboszorkákig. [New Witch Cults in the $20^{\text {th }}$ century. From the Wicca to Cyberwitches.] In Rubicon vol. 7: 56-61.

Lyotard, Jean-Francois. 1984. The Postmodern Condition. A Report on Knowledge. Trans. Geoff Bennington and Brian Massumi. (Theory and History of Literature vol. 10.) Manchester University Press.

Ross, Deborah. 2011 [1978]. Introduction. In Image and Pilgrimage in Christian Culture, eds. Victor Turner and Edith Turner, 1-16. New York: Columbia University Press.

Szilágyi, Tamás and Réka Szilárdi. 2007. Istenek ébredése. Az újpogányság vallástudományi vizsgálata. [The Awakening of Gods. The Religious Study of Neo-paganism.] Szeged: Szeged University Press.

Tiryakian, Edward A. 1996. Keresztény, gnosztikus, pogány. [Christian, Gnostic, Pagan.] In Lettre no. 23 (Winter)

http://www.c3.hu/scripta/lettre/lettre23/13tiry.htm (21 May 2015)

Turner, Victor and Edith Turner, eds. 2011 [1978]. Image and Pilgrimage in Christian Culture. New York: Columbia University Press. https://www.scribd.com/read/247840214/Image-and-Pilgrimage-in-ChristianCulture (22. May 2015)

Zentgraf, Manfred. Map of St. James' Way. Volkach, Germany. https://commons.wikimedia.org/wiki/File:Stjacquescompostelle1.png (02 Apr. 2015) 